\title{
Dental caries in children assisted on a dental school clinic: prevalence and associated factors
}

Emerson Tavares de Sousa ${ }^{a}$, Fabiana Barros Marinho Maia ${ }^{a}$, Vanessa Feitosa Alves ${ }^{a}$, Jaiza Samara Macena de Araújo ${ }^{a}$, Franklin Delano Soares Forte ${ }^{a}$, Fábio Correia Sampaio ${ }^{a}$

\begin{abstract}
OBJECTIVE: This study aimed to determine the factors associated with dental caries on primary and permanent dentition of a pediatric dental school clinic users.

METHODS: A retrospective study of information collected from 313 dental records obtained from 2011 to 2013. The prevalence of tooth decay on primary (dmft) and permanent dentition (DMFT). Sociodemographic factors, dietary and hygiene habits were analyzed, as well Data were analyzed using Chi-square or Fisher exact test $(\alpha=0.05)$.

RESULTS: Average dmft was $3.47 \pm 3.78$ and $3.46 \pm 3.05$ for $0-6$ and $7-9$ range age, respectively $(p=0.781)$. Average DMFT was $0.80 \pm 1.25$ and $3.16 \pm 3.72$ for the range of $7-9$ and $\geq 10$ years, respectively $(p=0.00)$. The restorative treatment need due to dental caries was highly prevalent (78\% of dmft and $54 \%$ of DMFT). Dmft was associated with paternal education (OR: $0.37,95 \% \mathrm{Cl}$ : 0.13-1.05) and OHI-S (OR: 2.39, 95\% Cl: 1.22-4.66). DMFT was associated with gender (OR: 2.36, 95\% Cl: 1.38-4.01).

CONCLUSION: Children assisted in this dental school clinic had a high prevalence of untreated dental caries, mainly associated with paternal education and OHI-S (primary dentition), and gender (permanent dentition).
\end{abstract}

Keywords: Health Services; Epidemiology; Dental caries

\section{Cárie dentária na dentição decidua e permanente em uma clínica escola de odontopediatria: prevalência e fatores associados}

\section{RESUMO}

OBJETIVO: Este estudo teve como objetivo determinar os fatores associados à cárie dentária na dentição decídua e permanente de usuários de uma clínica pública de Odontopediatria.

MÉTODOS: Foi realizado um estudo retrospectivo com informações coletadas de 313 prontuários odontológicos obtidos entre 2011 a 2013. Foram analisados a prevalência de cárie dentária na dentição primária (ceo) e permanente (CPO-D), assim como fatores sociodemográficos e hábitos dietéticos e de higiene oral. Os dados foram analisados utilizando teste Qui-quadrado ou exato de Fisher $(\alpha=0,05)$.

RESULTADOS: O ceo-d médio foi de 3,47 $\pm 3,78$ e 3,46 $\pm 3,05$ para as faixas etárias de 0-6 e 7-9, respectivamente $(p=0,781)$. O CPO-d médio foi de $0,80 \pm 1,25$ e 3,16 $\pm 3,72$ para as faixas de idade de $7-9$ e $\geq 10$ anos, respectivamente $(\mathrm{p}=0,00)$. A necessidade de tratamento restaurador devido à cárie dental foi altamente prevalente ( $78 \%$ do ceo-d e $54 \%$ do CPO-d). O ceo-d foi associado com educação paterna (OR: 0.37, IC 95\%: 0.13-1.05) e IHO-S (OR: 2.39, IC 95\%: 1.22-4.66). O DMFT foi associado ao gênero (OR: 2.36, IC 95\%: 1.38-4.01). CONCLUSÃO: As crianças atendidas nesta clínica escola de Odontopediatria apresentaram alta prevalência de cárie dentária não tratada, principalmente associada à educação paterna e IHO-S (dentição primária) e gênero (dentição permanente).

Palavras-chave: Serviços de saúde; Epidemiologia; Cárie dentária a Department of Clinical and Social Odontology School of Dentistry, Federal University of Paraiba, João Pessoa, Brazil.
Correspondence: Emerson Tavares de Sousa etsemerson@yahoo.com.br

Received: March 3, 2016 Accepted: June 19, 2017

Conflict of Interests: The authors state that there re no financial and personal conflicts of interest that could have inappropriately influenced their work.

Copyright: @ 2017 de Sousa et al licensee EDIPUCRS.

This work is licensed under a Creative Commons Attribution 4.0 International License. 


\section{INTRODUCTION}

The epidemiological reduction of caries incidence in the last years is a tendency around the world $[1,2,3]$. However, the dental caries is still a critical issue in public health because it is highly prevalent in specific groups of the population and demands many costs for health services $[4,5,6]$. From the community perspective, dental caries had demonstrated multiple manifestations that demand special attention, mainly due to its psychosocial and functional consequences [4], especially in early ages.

In this framework, understanding the distribution of caries is necessary to improve dental services and planning oral health strategies $[7,8]$. Therefore, epidemiological studies have evaluated the factors influencing the dental caries prevalence in children $[9,10,11]$. These studies are important to understand this disease in the public health context, promoting a movement of rational intervention at both community and individual levels. In this context, it is clear that public health services should have different dynamics considering some environmental, cultural and local factors that may influence the working process and the decision making of professionals [12].

Currently, the Unified Health System in Brazil has widely distributed Family Health Unities that promotes dental assistance in primary and secondary levels [13]. These services are established by Smiling Brazil policy approved in 2004. This policy also recognize that dental students must have access to an integral formation that considers all the aspects related to oral health diseases [14]. Thus, public dental schools clinics are an environment that promotes to the population a large variability of health services and provide a great contact between dental students and the community [15].

The services offered by public universities are commonly unpaid, have a good acceptability and are known as a reference service to the community. Therefore, these services are sought by patients with a diverse and complex treatment needs, which demand high versatility of management strategies and preventive tools $[15,16]$. Consequently, it is necessary to update information regarding the population's profile, as well as their characteristics and oral health necessities. Thus, this study aimed to determine the factors associated with dental caries on primary and permanent dentition of public pediatric dental clinic user., investigating sociodemographic factors an. dietary and oral hygiene habits.

\section{METHODS}

After approval of the local ethics committee (Health Science School - Paraíba Federal University. protocol 0186/2014), a retrospective study was carried out based on the analysis of dental records from the Cariology Clinic of Federal University of Paraiba (UFPB).

Three hundred and thirteen (313) records were selected from the population assisted from 2010 to 2013. Data were collected systematically considering demographic (Gender and Age), socioeconomic (Household Income and Paternal Education), dietary habits (Frequency and Type of Diet), hygiene habits (Frequency of Toothbrushing, Sulcus Bleeding Index - SBI and Simplified Oral Hygiene Index - OHI-S) - Box 1. Oral examinations were performed to estimate the dental caries experience on primary (dmft) and permanent (DMFT) according to WHO guidelines [8].

Data were analyzed using SPSS Statistics for Windows version 13.0 (SPSS, Inc., Chicago, IL, USA). The Chi-square $\left(\chi^{2}\right)$ and Fisher's exact tests were carried out to test the association between variables, as well the odds ratio (OR). The significance level was set at $\mathrm{p}<0.05$ (two-tailed).

Box 1. Theoretical framework of dmft and DMFT

\begin{tabular}{|lc|}
\hline \multicolumn{2}{|l|}{ Part 1. Socioeconomic and Demographic } \\
Variables & Category \\
Gender & Male; female \\
Household Income & $1-3$ minimum wage $(\mathrm{MW}),>4 \mathrm{MW}$ \\
Paternal Education & $\leq 5$ years; $>5$ years \\
Maternal Education & $\leq 5$ years; $>5$ years \\
\hline Part 2. Dietary Habits & \\
Variables & Category \\
Sugar Intake & $\leq 5$ times; $>5$ times \\
Type of Diet & Cariogenic; Non-Cariogenic \\
\hline Part 3. Hygiene Habits & \\
Variables & Category \\
Toothbrushing & $<2$ times per day; $\geq 3$ times per day \\
SBI Activity & High; Low \\
OHI-S & Good; Regular; Poor \\
\hline
\end{tabular}

\section{RESULTS}

The most common age group was $0-6$ years $(42.9 \%)$, followed by $10-16$ years $(31.4 \%)$ and $7-9$ years $(25.6 \%)$. The gender proportion was 1:1. The demand of restorative treatment was highly prevalent, demonstrating a proportion of 0.78 and 0.53 of dmft and DMFT index, respectively. The need for tooth extraction was found in merely 0.06 and 0.03 of the sample.

Table 1 demonstrated that there was no difference between dmft in 0-6 and 7-9 groups ( $\mathrm{p}=0.781)$. A significant difference was found between DMFT in 7-9 and $\geq 10$ age range $(p=0.000)$. There was a significant association between $\mathrm{dmft}$ and paternal education, as well as $\mathrm{dmft}$ and OHI-S (Table 2). DMFT was associated with gender (Table 3). 
Table 1. Dental caries experience in each age group

\begin{tabular}{ccc}
\hline Range age & \multicolumn{2}{c}{ Caries Experience } \\
& $\mathrm{dmft}( \pm \mathrm{SD})$ & $\mathrm{DMFT}( \pm \mathrm{SD})$ \\
0-6 years & $3.47( \pm 3.78)^{\mathrm{a}}$ & - \\
$7-9$ years & $3.46( \pm 3.05)^{\mathrm{a}}$ & $0.80( \pm 1.25)^{\mathrm{b}}$ \\
$\geq 10$ years & - & $3.16( \pm 3.72)^{\mathrm{a}}$ \\
\hline
\end{tabular}

Distinct letters are statistically different by Student t-test $(p<0.05)$.

Table 2. Factors associated with dental caries experience in primary dentition

\begin{tabular}{|c|c|c|c|c|c|c|c|c|c|c|}
\hline \multirow{3}{*}{\multicolumn{3}{|c|}{ Independent Variables }} & \multicolumn{8}{|c|}{ Caries Experience } \\
\hline & & & \multicolumn{2}{|c|}{$\mathrm{dmft}=0$} & \multicolumn{2}{|c|}{$\mathrm{dmft} \geq 1$} & \multicolumn{2}{|c|}{ Total } & \multirow{2}{*}{$\begin{array}{l}\text { Odds ratio } \\
\mathrm{Cl}(95 \%)\end{array}$} & \multirow{2}{*}{$\mathrm{p}$} \\
\hline & & & $\mathrm{n}$ & $\%$ & $\mathrm{n}$ & $\%$ & $\mathrm{n}$ & $\%$ & & \\
\hline \multirow{8}{*}{ 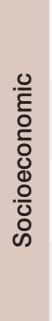 } & \multirow{2}{*}{ Gender } & Male & 37 & 15.7 & 90 & 38.1 & 127 & 53.8 & \multirow{2}{*}{$\begin{array}{c}0.68 \\
(0.39-1.17)\end{array}$} & \multirow{2}{*}{0.16} \\
\hline & & Female & 41 & 17.4 & 68 & 28.8 & 109 & 46.2 & & \\
\hline & \multirow{2}{*}{ Household Income } & 1-3 MW & 45 & 27.4 & 101 & 61.6 & 146 & 89 & \multirow{2}{*}{$\begin{array}{c}0.70 \\
(0.25-1.92)\end{array}$} & \multirow{2}{*}{0.48} \\
\hline & & $>4 \mathrm{MW}$ & 7 & 4.3 & 11 & 6.7 & 18 & 11 & & \\
\hline & \multirow{2}{*}{ Paternal Education } & $\leq 5$ years & 5 & 3.1 & 22 & 13.6 & 27 & 16.7 & \multirow{2}{*}{$\begin{array}{c}0.37 \\
(0.13-1.05)\end{array}$} & \multirow{2}{*}{$0.05^{\star}$} \\
\hline & & $>5$ years & 51 & 31.5 & 84 & 51.9 & 135 & 83.3 & & \\
\hline & \multirow{2}{*}{ Maternal Education } & $\leq 5$ years & 6 & 3.5 & 16 & 9.4 & 22 & 12.9 & \multirow{2}{*}{$\begin{array}{c}0.76 \\
(0.28-2.07)\end{array}$} & \multirow{2}{*}{0.59} \\
\hline & & $>5$ years & 49 & 28.7 & 100 & 58.5 & 149 & 87.1 & & \\
\hline \multirow{4}{*}{$\begin{array}{l}\frac{0}{0} \\
\frac{0}{0} \\
\frac{0}{2} \\
\frac{\pi}{\pi} \\
\frac{\pi}{0.0} \\
\frac{\overline{0}}{0}\end{array}$} & \multirow{2}{*}{ Sugar Intake } & $\leq 5$ times & 35 & 15.5 & 76 & 33.6 & 111 & 49.1 & \multirow{2}{*}{$\begin{array}{c}0.89 \\
(0.51-1.56)\end{array}$} & \multirow{2}{*}{0.70} \\
\hline & & $>5$ times & 39 & 17.3 & 76 & 33.6 & 115 & 50.9 & & \\
\hline & \multirow{2}{*}{ Type of Diet } & Cariogenic & 20 & 8.7 & 29 & 12.6 & 49 & 21.3 & \multirow{2}{*}{$\begin{array}{c}1.53 \\
(0.80-2.95)\end{array}$} & \multirow{2}{*}{0.19} \\
\hline & & Non-Cariogenic & 56 & 24.3 & 125 & 54.3 & 181 & 78.7 & & \\
\hline \multirow{6}{*}{ 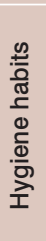 } & \multirow{2}{*}{ Brushing Frequency } & $<2$ times & 40 & 17.2 & 81 & 34.8 & 121 & 51.9 & \multirow{2}{*}{$\begin{array}{c}0.96 \\
(0.55-1.65)\end{array}$} & \multirow{2}{*}{0.88} \\
\hline & & $\geq 3$ times & 38 & 16.3 & 74 & 31.8 & 112 & 48.1 & & \\
\hline & \multirow{2}{*}{ SBI Activity } & High & 2 & 1.1 & 12 & 6.4 & 14 & 7.5 & 3.26 & 14 \\
\hline & & Low & 61 & 32.6 & 112 & 59.9 & 173 & 92.5 & $(0.70-15.0)$ & 0.14 \\
\hline & $\mathrm{OH} S \mathrm{C}$ & Regular & 25 & 13.9 & 26 & 14.4 & 51 & 28.3 & 2.391 & \\
\hline & OHI-S & Poor & 37 & 20.6 & 92 & 51.1 & 129 & 71.7 & $(1.22-4.66)$ & $0.01^{*}$ \\
\hline
\end{tabular}

MW: Minimum wage (s); * Chi-square or Fisher's exact significant.

Table 3. Aspects associated with caries experience in pemanent teeth

\begin{tabular}{|c|c|c|c|c|c|c|c|c|c|c|}
\hline & & & & & & Carie & erien & & & \\
\hline & Independen & Variables & & & & & & & Odds ratio & \\
\hline & & & $\mathrm{n}$ & $\%$ & $n$ & $\%$ & $\mathrm{n}$ & $\%$ & IC (95\%) & $p$ \\
\hline & Condor & Male & 82 & 35.3 & 41 & 17.7 & 123 & 53 & 2.36 & \\
\hline & Gerruer & Female & 50 & 21.6 & 59 & 25.4 & 109 & 47 & $(1.38-4.01)$ & $0.00^{*}$ \\
\hline 을 & Household Income & 1-3 MW & 75 & 50.7 & 55 & 37.2 & 130 & 87.8 & 0.68 & 046 \\
\hline ठํㅇㅇ & Housenota income & $>4 \mathrm{MW}$ & 12 & 8.1 & 6 & 4.1 & 18 & 12.2 & $(0.24-1.92)$ & 0.40 \\
\hline 잉 & Paternal Fducation & $\leq 5$ years & 15 & 9.8 & 8 & 5.2 & 23 & 15 & 1.37 & 049 \\
\hline "ত্ঠ & raternal Education & $>5$ years & 75 & 49 & 55 & 35.9 & 130 & 85 & $(0.54-3.47)$ & 0.49 \\
\hline & & $\leq 5$ years & 12 & 7.2 & 9 & 5.4 & 21 & 12.6 & 1.01 & \\
\hline & Maternal Education & $>5$ years & 83 & 49.7 & 63 & 37.7 & 146 & 87.4 & $(0.40-2.55)$ & 0.98 \\
\hline$\frac{n}{\frac{\pi}{0}}$ & & $\leq 5$ times & 64 & 29.1 & 50 & 22.7 & 114 & 51.8 & 0.94 & \\
\hline$\frac{\sqrt{\pi}}{\underline{\simeq}}$ & sugar Frequency & $>5$ times & 61 & 27.7 & 45 & 20.5 & 106 & 48.2 & $(0.55-1.61)$ & 0.83 \\
\hline 胥 & Tyne of Riet & Cariogenic & 31 & 13.8 & 15 & 6.7 & 46 & 20.4 & 1.70 & 012 \\
\hline$\frac{\Phi}{0}$ & Iype or Det & Non-Cariogenic & 98 & 43.6 & 81 & 36 & 179 & 79.6 & $(0.86-3.38)$ & 0.12 \\
\hline & Brushing Frecuency & $>2$ times & 61 & 26.5 & 47 & 20.4 & 108 & 47 & 0.93 & \\
\hline$\stackrel{\infty}{ \pm}$ & Brusning rrequency & $\geq 3$ times & 71 & 30.9 & 51 & 22.2 & 122 & 53 & $(0.55-1.57)$ & 0.79 \\
\hline 可 & SRI Artivity & High & 11 & 5.8 & 7 & 3.7 & 18 & 9.4 & 0.75 & \\
\hline$\stackrel{\Phi}{c}$ & ડBI ACtIVIty & Low & 94 & 49.2 & 79 & 41.4 & 173 & 90.6 & $(0.28-2.04)$ & 0.58 \\
\hline$\frac{0}{7}$ & & Good & 38 & 19.6 & 24 & 12.4 & 62 & 32 & & \\
\hline 조 & OHI-S & Regular & 49 & 25.3 & 47 & 24.1 & 95 & 49.4 & - & 0.39 \\
\hline & & Poor & 18 & 9.3 & 18 & 9.3 & 36 & 18.6 & & \\
\hline
\end{tabular}

MW: Minimum wage (s); * Chi-square or Fisher's exact significant. 


\section{DISCUSSION}

Dental records analyzed in this research demonstrated a reality of individuals who are economically vulnerable and that have high experience of dental caries. This tendency highlighted the necessity of tools development for identifying environmental and social needs beyond the dental needs.

Children who attended this public clinic have high necessity of dental treatment, presented expressive scores of "decayed" component. This result demonstrated the lack of health care access to these children. Many factors contribute to the absence of dental care access to low-income children. These factors might be the socioeconomic and psychological status of parents, difficulties in booking a consultation or transportation, fear of the dentist, and oral health myths $[17,18]$. In this sense, more important than use this information to preview and planning the health services in dental clinic schools is to understand this reality as a peculiar one, that demands a better comprehension by professors and students [18, 19,20,21].

Socioeconomic status was not associated with DMFT and $\mathrm{dmft}$. These outcomes are important because prove that little improvement in educational qualification and household income did not reduce significantly the disease prevalence. In this context, it is prudent to notice that in this study the volunteers mostly had low household incomes (below three minimum wages) and schooling (until high school). Some studies have considered the individual contribution of socioeconomic context or the development of dental caries in children $[22,23]$. These studies found that social status, low paternal education, and low family income provide worst oral health conditions [24, 25, 26, 27, 28, 29]. On the other hand, other studies have demonstrated that these factors cannot be considered a determining factor [30].

Paternal education was a protective factor (OR: 0.37) for dental caries in primary dentition. This results contrast with another author that considered the maternal education as the most important predictor for early childhood caries [26,27]. In this sense, this investigation was not able to find any significant difference between maternal education and their effective contribution to dental caries prevalence. These results can be explained by the sample composition that has low level of schooling. Besides, it is difficult to make a more accurate comparison from this variable due to the different perspectives of the learning process and teaching quality.

Dietary habits were not significantly associated with dmft and DMFT. These results can be considered a paradox, considering the etiology of dental caries $[30,31,32]$. Therefore, we considered that these results are consequence of the lack of information regarding the fulfillment of dietary diary. This question could be more accurately assessed if the dentist makes an interview to complement the information of the dietary diary.

The toothbrushing frequency was not associated with DMFT. At this point, it is important to evidence that verbal information about poor habits of hygiene is commonly hidden by the parents $[33,34]$. Clinically, the parameters frequently used to sign poor oral hygiene are OHI-S and SBI [35]. However, in our investigation we did not find any association with the prevalence of dental caries. These outcomes possibly indicated that these parameters were not good predictors of dental caries in a sick population who is attended in public pediatric clinics. Similarly, Cascaes et al. [34] suggests that the frequency of brushing alone is not enough to assess oral hygiene in children. Thus, we considered that this tendency can be explained by two important pathways: firstly, it is common that children brush better their teeth before going to dental consultations; secondly, parents and children usually hide information about their daily habits.

\section{CONCLUSION}

Children attended in a public dental clinic had a high prevalence of untreated dental caries, mainly associated with paternal education and OHI-S (primary dentition), and gender (permanent dentition). Moreover, our findings highlighted the necessity of developing educational strategies for dental students take effective care of children with social deprivation.

\section{REFERENCES}

1. Edelstein BL. The dental caries pandemic and disparities problem. BMC Oral Health. 2006;6:S2. https://doi.org/10.1186/1472-6831-6-S1-S2

2. Da Rosa P, Nicolau B, Brodeur JM, Benigeri M, Bedos C, Rousseau MC Associations between school deprivation indices and oral health status. Community Dent Oral Epidemiol. 2011;39:213-20. https://doi.org/10.1111/ j.1600-0528.2010.00592.x

3. Narvai PC, Frazão P, Roncalli AG, Antunes JL. Dental caries in Brazil: decline. polarization. inequality and social exclusion. Rev Panam Salud Publica. 2006;19:385-93. https://doi.org/10.1590/S102049892006000600004

4. Zukanović A. Caries risk assessment models in caries prediction. Acta Medica Academ 2013;42:198-208. https://doi.org/10.5644/ama2006124.87

5. World Health Organization. Oral health surveys: basic methods. 4⿳亠丷a ed Geneva: ORH/EPID. 1997

6. Ferreira SH, Béria JU, Kramer PF, Feldens EG, Feldens CA. Dental caries in 0-to-5-year old Brazilian children prevalence, severity and associated factors. Int J Paediatric Dent. 2007;17:289-96. https://doi.org/10.1111/ j.1365-263X.2007.00831.X

7. Harris R, Nicoll AD, Adair PM, Pine CM. Risk factors for dental caries in young children: a systematic review of the literature. Community Dent Health. 2004;21:71S-85S

8. Gao XL, Hsu CYS, Xu Y, Hwarng HB, Loh T, Koh D. Building Caries Risk Assessment Models for Children. J Dent Res. 2010;89:637-43. https://doi. org/10.1177/0022034510364489

9. Selwitz RH, Ismail Al, Pitts NB. Dental caries. Lancet. 2007:369:51-9. http://dx.doi.org/10.1016/S0140-6736(07)60031-2

10. Sayegh A, Dini EL, Holt RD, Bedi R. Oral health, sociodemographic factors, dietary and oral hygiene practices in Jordanian children. J Dent. 2005;33:379-88. https://doi.org/10.1016/j.jdent.2004.10.015

11. Petersen PE. Sociobehavioural risk factors in dental caries - international perspectives. Community Dent Oral Epidemiol. 2005;33:274-79. https:// doi.org/10.1111/j.1600-0528.2005.00235.x

12. Wright FA, List PF. Reforming the mission of public dental services Community Dent Oral Epidemiol. 2012;40:102-9. https://doi: 10.1111/ j.1600-0528.2012.00728.x

13. Pucca Junior GA, Costa JFR, Chagas LD, Silvestre RM. Oral health policies in Brazil. Braz. Oral Res. 2009;23:9-16. http://dx.doi.org/10.1590/ S1806-83242009000500003 
14. Brasil. Ministério da Saúde. Diretrizes da política nacional de saúde bucal. 2004, in Portuguese.

15. Formicola AJ, Myers R, Hasler JF, Peterson M, Dodge W, Bailit HL, Beazoglou T, Tedesco LA. Evolution of Dental School Clinics as Patient Care Delivery Centers. J Dent Edu. 2006;70:1271-88.

16. Forcomila AJ. Dental School Clinics as Patient Care Delivery Centers: A Paradigm Shift in Dental Education. J Dent Edu. 2008;72:18-20.

17. Antunes JLF, Peres MA, de Campos MTR, Waldman EA. Multileve assessment of determinants of dental caries experience in Brazil Community Dent Oral Epidemiol. 2006;34:146-52. https://doi.org/10.1111/ j.1600-0528.2006.00274.x

18. Ministério da Saúde: Projeto SB Brasil 2010: condições de saúde bucal da população brasileira: resultados principais. Brasil: Brasília: Departamento de Atenção Básica. Secretaria de Atenção à Saúde. Ministério da Saúde. 2010, in Portuguese.

19. Telleen S, Rhee Kim YO, Chavez N, Barrett RE, Hall W, Gajendra S Access to oral health services for urban low-income Latino children: social ecological influences. J Public Health Dent. 2012;72:8-18. https://doi. org/10.1111/j.1752-7325.2011.00275.x

20. Donaldson $M$, Kinirons $M$. The effectiveness of the school dental screening program in stimulating dental attendance for children in need of treatment in Northern Ireland. Community Dent Oral Epidemiol. 2001;29:143-49. https://doi.org/10.1034/j.1600-0528.2001.290209.x

21. Hebbal M, Nagarajappa R. Does school-based dental screening for children increase follow-up treatment at dental school clinics? J Dent Educ. 2005;69:382-6.

22. Pizzo G, Piscopo MR, Matranga D, Luparello M, Pizzo I, Giuliana G. Prevalence and socio-behavioral determinants of dental caries in Sicilian schoolchildren. Med Sci Monit. 2010;16:PH83-9

23. Marshall TA, Eichenberger-Gilmore JM, Broffitt BA, Warren JJ, Levy SM Dental caries and childhood obesity: roles of diet and socioeconomic status. Comm Dent Oral Epidemiol. 2007;35: 449-58. https://doi:10.1111/ j.1600-0528.2006.00353.x

24. Lisboa CM, de Paula JS, Ambrosano GMB, Pereira AC, Meneghim $\mathrm{MC}$, Cortellazzi KL, Vazquez FL, Mialhe FL. Socioeconomic and family influences on dental treatment needs among Brazilian underprivileged schoolchildren participating in a dental health program. BMC Oral Health. 2013;13:56. https://doi.org/10.1186/1472-6831-13-56

25. Postma TC, Ayo-Yusuf AO, van Wyk PJ. Socio-demographic correlates of early childhood caries prevalence and severity in a developing country-
South Africa. Int Dent J. 2008:58:91-7. https://doi.org/10.1111/j.1875595X.2008.tb00182.x

26. Traebert J, Guimaraes LA, Durante EZ, Serratine AC. Low maternal schooling and severity of dental caries in Brazilian preschool children. Oral Health Prev Dent. 2009;7:39-45.

27. Kim SW. Environmental, maternal, and child factors which contribute to early childhood caries: a unifying conceptual model. Int J Paediatr Dent. 2012; 22:157-68. https://doi.org/10.1111/j.1365-263X.2011.01186.x

28. Mariño RJ, Calache H, Whelan M. Socio-demographic profile of child and adolescent users of oral health services in Victoria. Australia. Cad. Saúde Pública. 2014;30:1903-11

29. Martins MT, Sardenberg F, Abreu MH, Vale MP, Paiva SM, Pordeus IA Factors associated with dental caries in Brazilian children: a multilevel approach. Community Dent Oral Epidemiol. 2014;42:289-99. https://doi. org/10.1111/cdoe. 12087

30. Du M, Bian Z, Guo L, Holt R, Champion J, Bedi R. Caries patterns and their relationship to infant feeding and socio-economic status in 2-4-year-old Chinese children. Int Dent J. 2000;50:385-89. https://doi.org/10.1111/ j.1875-595X.2000.tb00573.X

31. Pitts N, Amaechi B, Niederman R, Acevedo AM, Vianna R, Ganss C Ismail A, Honkala E. Global oral health inequalities: dental caries task group--research agenda. Adv Dent Res. 2011;23:211-20. https://doi: 10.1177/0022034511402016

32. Nunes AMM, da Silva AAM, Alves CMC, Hugo FN, Ribeiro CCC Factors underlying the polarization of early childhood caries within a high-risk population. BMC Public Health. 2014;14:988. https://doi. org/10.1186/1471-2458-14-988

33. Choo A, Delac DM, Messer LB. Oral hygiene measures and promotion: review and considerations. Aust Dent J. 2001;46:166-73. https://doi org/10.1111/j.1834-7819.2001.tb00277.x

34. Cascaes AM, Peres KG, Peres MA, Demarco FF, Santos I, Matijasevich A Barros AJD. Validade do padrão de higiene bucal de crianças aos cinco anos de idade relatado pelas mães. Rev Saúde Pública. 2011;45:668-75. https://doi.org/10.1590/S0034-89102011005000033

35. Wei SH, Lang NP. Periodontal epidemiological indices for children and adolescents: II. Evaluation of oral hygiene; III. Clinical applications. Pediatr Dent. 1982;4:64-73 